Heart Failure (STICH) trial. The Journal of Thoracic and Cardiovascular Surgery, 134 (6), 1540-1547. doi: 10.1016/ j.jtcvs.2007.05.069
11. Bonow, R., Maurer, O., Lee, K. (2011). Myocardial Viability and Survival in Ischemic Left Ventricular Dysfunction. New England Journal of Medicine, 364, 1617-1625.

Рекомендовано до публікації д-р мед. наук Целуйко В. Й. Дата надходження рукопису 14.01.2015

Кузнецов Игорь Владимирович, кандидат медицинских наук, доцент, кафедра кардиологии и функциональной диагностики, Харьковская медицинская академия последипломного образования, ул. Корчагинцев, 48, г. Харьков, Украина, 61168

E-mail: kyznetsov_i_v@mail.ru

УДК 616-092.19

DOI: 10.15587/2313-8416.2015.37901

\title{
ЛАКТАТАЦИДОЗ ПРИ СЕПСИСІ У ДІТЕЙ
}

\section{(C) В. А. Корсунов}

У статті проведено детальний аналіз сучасних даних щзодо механізмів розвитку та клінічного значення лактат-ацидозу при септичних станах. Представлено результати власних досліджень стану кисневого транспорту, КОС, рівня лактату, ичентральної гемодинаміки та органного кровоплину у 103 дітей із септичними станами. Продемонстровано залеженість гіперлактатемії від розладів метаболізму та відсутність зв'язку з розладами гемодинаміки. Констатовано негативний вплив гіперлактатемії на тяжкість органних розладів та виходи при сепсисі у дітей

Ключові слова: діти, сепсис, тяжкий сепсис, септичний шок, синдром поліорганної недостатності, лактат, оксид азоту, ендотелін, мікрочиикуляція, гемодинаміка

Aim. To determine the leading mechanisms of lactic acidosis course it is conducted a detailed analysis of scientific papers on this issue, and on the basis of modern scientific basis to conduct the study of the state of hemodynamics, metabolism and acid-base balance in pediatric sepsis.

Methods. To achieve this aim it was used to identify indicators of central and organ hemodynamics by Doppler ultrasound, were studied the ABB indicators of central venous and arterial blood electrolytes, creatinine, urea, lactate, endothelin, serum metabolites of nitric oxide. SOFA and Glasgow scales are used.

Result. The results of the study gave reason to believe that lactic acidosis in pediatric sepsis is not caused by disorders of the central and organ (liver, mesenteric, renal) hemodynamics. Instead it is revealed the relationship between course of lactic acidosis and presence of hyperglycemia. A negative impact of lactic acidosis on the severity of multiple organ dysfunction syndrome (MODS) and outputs in pediatric sepsis is stated.

Conclusions. Thus, summing up the results obtained in the study, we conclude that hyper lactic acidosis in pediatric sepsis is an important marker for disorders of energy metabolism and an independent marker of unfavorable prognosis and a high risk of MODS

Keywords: children, sepsis, severe sepsis, septic shock, multiple organ dysfunction syndrome, lactate, nitric oxide, endothelin, microcirculation, hemodynamics

\section{1. Вступ}

Лактатацидоз є відомим маркером тканинної гіпоксії. Існує думка щодо можливості використання цього показника для діагностики тяжкого сепсису (ТC) та септичного шоку (СШ). Вважається що лактатацідоз $€$ надійним підтвердженням розладів перфузії при цих станах. У той же час відомі дослідження, які заперечують тісний зв'язок між рівнем лактату та тяжкістю розладів органної перфузії. На думку авторі цих робіт підвищення вмісту лактату у крові може бути обумовлене розладами метаболізму глюкози, а саме надмірним ії споживанням клітинами імунної системи під час реалізації системної запальної відповіді. Отже, постає питання щодо об'єктивної оцінки лактатацідозу при сепсисі у дітей.

\section{2. Постановка проблеми}

3 огляду на вищезазначену інформацію представляється доцільним та корисним для клінічної практики провести детальний аналіз наукових робіт присвячених проблемам лактатацидозу та, на підставі сучасного наукового базису провести вивчення стану гемодинаміки, метаболізму, КОС у дітей з сепсисом з метою пошуку відповіді на поставлене запитання.

\section{3. Літературний огляд}

Тривалий час основним маркером тканинної гіпоксії вважався лактат, який $є$ кінцевим продуктом гліколізу. У нормі його продукція становить 1 мекв/(кг/год). Велика частка утвореного лактату 
метаболізується у печінці як субстрат для глюконеогенезу, менша - у міккарді у якості джерела енергії [1]. За неможливості безпосереднього вимірювання рівня лактату, з достатньо високою часткою упевненості можна стверджувати, що у пацієнта $є$ лактатацидоз, якщо величина аніонного інтервалу перевищує 30 ммоль/л і відсутній кетоацидоз [1-3]. В умовах гіпоксії коефіцієнт кореляції (r) між концентрацією лактату і розміром аніонного інтервалу складає 0,92 [4].

Очевидно, що причинами підвищення рівня лактату можуть бути чинники, що впливають як на збільшення його продукції, так і на зменшення його утилізації. Сепсис, СШ і СПОН є найбільш частими причинами розвитку L-лактат-ацидозу. Тривалий час вважали, що причиною лактат-ацидозу при сепсисі $є$ циркуляторна гіпоксія, що виникає внаслідок гіпоперфузії тканин. Добре відомо, що в анаеробних умовах піруват не надходить до циклу трикарбонових кислот, а під дією лактатдегідрогенази перетворюється на лактат. При цьому утворюється лише 2 молекули АТФ, які, віддаючи іон водню, утворюють АДФ, а іон водню з'єднується з лактатом, утворюючи молочну кислоту. Проте, це не єдина причина лактат-ацидозу, адже через ішемію печінки може страждати утилізація лактату.

Підвищення рівня молочної кислоти в крові понад 2,0 ммоль/л є одним із критеріїв для діагностики тяжкого сепсису (ТС) і септичного шоку (СШ), а підвищення понад 4,0 ммоль/л є досить точним маркером розвитку синдрому поліорганної недостатності (СПОН) і поганого прогнозу в септичних пацієнтів [5]. Також відомо, що збільшення кліренсу лактату асоціюється з покращенням виходів при ТС та СШ [4]. Якщо на тлі інтенсивної терапії рівень лактату знижується нижче 3,5 ммоль/л, то виживає $90 \%$ пацієнтів, якщо він залишається на рівні до 5,5 ммоль/л - 63 \%, до 7,5 ммоль/л - 43 \%. У тих випадках, коли, не зважаючи на терапію, рівень лактату залишається понад 9,0 ммоль/л - виживає лише 7 \% хворих [6]. Але ця інформація була б не повною, якби ми не сказали, що при сепсисі підвищення рівня лактату буває навіть у тих випадках, коли системної гіпоксії немає, або навіть доставка кисню перевищує норму. Сьогодні відомо, що багато гострих станів супроводжуються інсулінорезистентністю, порушенням толерантності до глюкози і гіперглікемією, що отримало назву «травматичного діабету». При цьому, попри гіперглікемію та інсулінорезистентність, відбувається збільшення продукції глюкози в печінці в результаті глюконеогенезу [5]. Разом із тим, споживання глюкози в різних тканинах при шоку змінюється по-різному. Наприклад, у міокарді та скелетних м'язах інсулінзалежне споживання глюкози порушується, а в клітинах ЦНС і еритроцитах - зростає. Отримані експериментальні дані про те, що ряд цитокінів, ендотелін, гіпоксія та інші чинники порушують регуляцію експресії транспортних систем для глюкози в тих типах тканин, які споживають глюкозу незалежно від інсуліну. При цьому відбувається інтенсивне надходження глюкози до клітини і перевантаження нею внутріклітинного компартменту [7, 8]. Внаслідок цього порушується робота мітохондрій, які вимушені генерувати більшу кількість енергії (отже - споживати кисень, продукувати вуглекислий газ і тепло). При цьому у хворих на СШ утворюються значні кількості супероксиддисмутази, пероксинітриту, токсичних продуктів, які підсилюють апоптоз. Таким чином, наслідком гіперглікемії і інсулінорезистентності $€$ не тільки гіперметаболізм, але і токсичне пошкодження життєвоважливих клітин і тканин циркулюючою глюкозою, з подальшим порушенням функції печінки, імунної системи, ендотелію, ниркових канальців та ін. Отже, активація инсуліннезалежних мембранних транспортерів під впливом ендотоксину і цитокінів викликає активацію споживання глюкози клітинами та гіперпродукцію пірувату, тобто, не лише гіпоксія, але і вуглеводний гіперметаболізм $є$ важливим чинником сепсис-індукованої гіперлактатемії, що пояснює наявність лактат-ацидозу навіть у хворих з адекватною перфузією [7, 8].

Гіперлактатемія може спостерігатись також на тлі інфузії адреналіну, нітропрусиду натрію, при епілептичних нападах, тривалому алкалозі, введенні надмірної кількості фруктози, сорбіту, або ксиліту, нестачі тіаміну, вроджених захворюваннях, що супроводжуються розладами вуглеводного обміну (глікогеноз I типу, дефіцит глюкозо-6-фосфатази, фруктозо-1,6-діфосфатази, піруватдекарбоксилази, піруваткарбоксилази, дігідроліпоілтрансацетилази, дігідроліпоілдегідрогенази, фосфатази піруватдегідрогенази, дефіцит карнітину, вроджений ідіопатичний лактатацидоз, некротизуюча енцефалопатія Лі) $[9,10]$. Також відомо, що окремі судинні басейни (кишечник) можуть зазнавати гіпоксії, але не утворювати надлишок лактату. Таким чином, гіперлактатемія може спостерігатися за відсутності гіпоксії або бути відсутньою за її наявності [5].

Отже, виходячи 3 наведених даних, необхідно зробити припущення, що рівень лактату у крові не може бути абсолютно надійним маркером тканинної оксигенації.

\section{4. Характеристика стану центральної та} регіонарної гемодинаміки, КОС, метаболізму та вмісту вазоактивних медіаторів, залежно від рівня лактату сироватки при септичних станах у дітей.

3 метою з'ясування механізмів гіперлактатемії при сепсисі та її впливу на виходи при септичних станах було проведено дослідження до якого включено 103 пацієнти дитячого віку із С, ТС та СШ. Усіх хворих залежно від рівню лактату було розподілено на хворих із лактатом, понад 2,5 ммоль/л у центральній венозній крові $(\mathrm{n}=53,(51 \pm 5 \%))$; та хворих із лактатом менше 2,5 ммоль/л у центральній венозній крові $(\mathrm{n}=50,(49 \pm 5 \%))$.

Аналіз показників віку, росту, маси тіла, площі поверхні тіла (ППТ) та гендерної характеристики дав підстави стверджувати, що хворі досліджуваних груп достовірно не відрізнялись (р>0,05) (табл. 1). 
Таблиця 1

Загальна характеристика груп з високим та низьким рівнем лактату $(\mathrm{x} \pm \mathrm{Sx})$

\begin{tabular}{|l|c|c|c|}
\hline \multicolumn{1}{|c|}{ Показники } & $\begin{array}{c}\text { Лактат } \\
>2,5 \text { ммоль/л, } \\
\mathrm{n}=53\end{array}$ & $\begin{array}{c}\text { Лактат } \\
2,5 \text { ммоль/л, } \\
\mathrm{n}=50\end{array}$ & $\mathrm{p}$ \\
\hline Вік, міс. & $40,2 \pm 9,4$ & $33,7 \pm 7,7$ & $>0,05$ \\
\hline $\begin{array}{l}\text { Стать, хлопчики/ } \\
\text { дівчинки }\end{array}$ & $19 / 23$ & $17 / 14$ & $>0,05$ \\
\hline Довжина тіла, см & $94,3 \pm 5,3$ & $93,1 \pm 5,6$ & $>0,05$ \\
\hline Маса тіла, кг & $14,2 \pm 2,2$ & $13,7 \pm 1,9$ & $>0,05$ \\
\hline ППТ, ${ }^{2}$ & $0,59 \pm 0,06$ & $0,58 \pm 0,06$ & $>0,05$ \\
\hline
\end{tabular}

Для досягнення поставленої мети всі хворі були детально обстежені. Діагноз сепсису, тяжкого сепсису та септичного шоку визначався за критеріями консенcycy SCCM/ESICM/ACCP/ATS/SIS International Sepsis Definitions Conference, 2002. Рівень свідомості під час дослідження визначали за модифікованою шкалою Глазго для дорослих і дітей (Reilly P. L., Simpson D. A., Sprod R., Thomas L., 1988), Тяжкість СПОН та функціонального дефіциту органів та систем оцінювалися за шкалою SOFA (1994). Усім хворим проводили вимірювання погодинного діурезу.

Клінічне дослідження крові проводили за загальноприйнятими методами.

Гематокрит у венозній та артеріальній крові досліджували за допомогою центрифугування гепаринізованої крові. Оцінка $\mathrm{pH}$ та вмісту електролітів $\left(\mathrm{K}^{+}, \mathrm{Na}^{+}, \mathrm{iCa}^{++}\right)$у плазмі виконували за допомогою аналізатора «AVL-998-4» (Австрія). Показники KOC i газів артеріальної та центральної венозної крові $\left(\mathrm{pO}_{2}\right.$, $\left.\mathrm{pCO}_{2}, \mathrm{SaO}_{2}, \mathrm{pH}, \mathrm{HCO}_{3}^{-}, \mathrm{BE}, \mathrm{BB}\right)$ визначали за допомогою аналізаторів AVL-995 (Австрія) та Gastat-mini (Японія). Аніонний інтервал (Аgap) розраховували за формулою:

$$
\text { Agap }=\left[\mathrm{Na}^{+}\right]-\left[\mathrm{Cl}^{-}\right]-\left[\mathrm{HCO}_{3}^{-}\right]
$$

Рівень глюкози крові визначали за допомогою аналізатора «ЕКСАН-Г». Концентрацію сечовини в крові та в добовій сечі визначали методом кольорової реакції з діазоацетилмонооксимом («Філісіт» Україна), із наступним розрахунком добової втрати білка за методом Е. В. Крастиня і співавторів (1976) за формулою:

Добова втрата білка=Добова кількість сечовини сечі*46,6/80 г азоту/добу.

Вміст лактату крові визначали ензиматичним методом - «Ольвекс диагностикум» (Росія). Всі біохімічні дослідження проводили на біохімічному напівавтоматичному аналізаторі Stat Fax $1904^{+}$(США).

Концентрацію C-реактивного протеїну визначали імуноферментним методом (ELISA-test, «CRP EIA KIT», США). Вміст ендотеліну (1-21) сироватки визначали імуноферментним методом за допомогою наборів «Biomedica» (Німеччина). Вміст NO сироватки оцінювали за кінцевими метаболітами (нітрити/ нітрати) колориметричним методом за допомогою реактиву Гриса у ЦНДЛ Харківського національного медичного університету.

Моніторне спостереження за пацієнтами включало визначення ЕКГ, частоти серцевих скорочень (ЧСС), пульсоксиметрію (SpO2), вимірювання середнього артеріального тиску (САТ) осцилометрічним методом, контроль ЦВТ (монітори UM-300, Україна, «Brucker», Німеччина).

До початку лікування та на етапах інтенсивної терапії всім хворим проводили ехокардіоскопію у М-режимі та імпульсно-хвильове допплерівське сканування трансмітрального кровоплину за допомогою УЗ-сканерів “Ultima PA" (Україна) та "Sono-Sayt Titan”, США. Вимірювали кінцево-діастолічний (КДР) та кінцево-систолічний (КСР) розміри ЛШ. На підставі отриманих даних за формулою Teichholz L et al, (1976) проводили розрахунок індексів кінцево-систолічного (ІКСО) та кінцево-діастолічного об’ємів (ІКДО) ЛШ, ударного індексу (УІ), фракції викиду (ФВ). Серцевий індекс розраховували за формулою:

\section{$\mathrm{CI}=\mathrm{YI} * \mathrm{ЧCC}$.}

Також вимірювали параметри трансмітрального кровоплину: максимальні швидкості хвиль раннього діастолічного наповнення (E) (Vmax E) та передсердної систоли (A) (Vmax A), мінімальні швидкості $\mathrm{E}(\mathrm{Vmin} \mathrm{E})$ та A (Vmin A), розраховували показник співвідношення максимальної швидкості хвилі раннього діастолічного наповнення до максимальної швидкості хвилі передсердної систоли

\section{$\mathrm{E} / \mathrm{A}=\mathrm{Vmax} \mathrm{E}$ ЛШ/Vmax А ЛШ.}

Середній артеріальний тиск у легеневій артерії (САТ ЛА) вимірювали за Kitabatake A et al., (1983).

Всім пацієнтам проводили імпульсно-хвильове допплерівське сканування кровоплину по правій нирковій (A ren D) та лівій нирковій (A ren S) артеріях та правій (V ren D) та лівій (V ren S) нирковій венах (У3-сканер “Ultima PA”). Вимірювали максимальну (Vmax) та мінімальну (Vmin) швидкості кровоплину по цих судинах. На підставі отриманих даних розраховували середню швидкість кровоплину (Vmean), пульсаційний індекс (PI) та індекс резистентності (IR).

Також вимірювали діаметри судин (D): портальної вени (VP), селезінкової вени (VL), печінкової артерії (AH), селезінкової артерії (AL), верхньої мезентеріальної артерії (AM), максимальну (Vmax) та мінімальну (Vmin) швидкості кровоплину по цих судинах. На підставі отриманих даних за загальновідомими формулами розраховували середню швидкість кровоплину (Vmean), пульсаційний індекс (PA), індекс резистентності (IR), об'ємний кровоплин Q, співвідношення кровоплину до маси тіла $\mathrm{Q} / \mathrm{m}$. Також розраховували індекси об'ємного кровоплину по печінковій артерії за формулою:

IOK $\mathrm{AH}=3,14 * \mathrm{DAH}^{2 *} 1,055 *$

*Vmean AH*ЧСС (Щетинин В.П., 2002), 
та верхній мезентеріальній артерії за формулою:

IOK $\mathrm{AM}=3,14 * \mathrm{D} \mathrm{AM}^{2} * 1,055^{*}$ Vmean Ames*

*ЧСС (Щетинин В.П., 2002),

та їх співвідношення до СI (ОК/CI АН та ОК/CI AM). Крім цього, розраховували загальний печінковий об'ємний кровоплин:

\section{ЗПОК=Q VP+Q АН (Щетинин В. П., 2002).}

Проводили розрахунок:

- доставки кисню за формулою:

$\mathrm{DO}_{2},=\mathrm{CI} * \mathrm{CaO}_{2}$,

- споживання кисню за формулою:

$$
\mathrm{VO}_{2},=\mathrm{CI} *\left(\mathrm{CaO}_{2}-\mathrm{CvO}_{2}\right)
$$

- індексу тканинної екстракції кисню за формулою:

$$
\mathrm{ITEO}_{2}=\mathrm{DO}_{2} / \mathrm{VO}_{2} \text { (Morgan G., Mikhail M., 1996). }
$$

Методи статистичного та математичного аналізу. На підставі одержаних результатів створено базу даних у пакетах «Microsoft-Works 97» та «Statistica 6». Одержані дані оброблено на ПЕОМ IBM-PC-AT, за допомогою програм "Microsoft Works 97" та "Statistica 6". Оцінку достовірності відмінностей величин між групами проводили на підставі параметричного критерію t (Ст'юдента). Наявність кореляцій між отриманими показниками визначали за непараметричним критерієм rs (Спірмена).

\section{5. Апробація результатів дослідження}

Пацієнти 3 рівнем лактату $>2,5$ ммоль/л та $<2,5$ ммоль/л характеризувались наявністю клініко-лабораторних ознак синдрому системної запальної відповіді у вигляді лейкоцитозу, зсуву лейкоцитарної формули вліво, гарячкою та збільшенням понад норму (6 мг/л) СРП. Проте, цікаво відзначити, що рівень СРП у хворих лактатом $<2,5$ ммоль/л, хоча і перевищував норму, але був достовірно нижчим, ніж у хворих $з$ лактатом $>2,5$ ммоль/л ( $<0,01)$ (табл. 2).

Таблиця 2

Показники тяжкості системної запальної відповіді залежно від рівня лактату $(\mathrm{x} \pm \mathrm{Sx})$

\begin{tabular}{|l|c|c|c|}
\multicolumn{1}{|c|}{ Показники } & $\begin{array}{c}\text { Лактат } \\
>2,5 \text { ммоль/л }\end{array}$ & $\begin{array}{c}\text { Лактат } \\
<2,5 \text { ммоль/л }\end{array}$ & $\mathrm{p}$ \\
\hline Лейкоцити, $10^{9} / л$ & $17,5 \pm 1,6$ & $19,6 \pm 1,4$ & $>0,05$ \\
\hline$\%$ молодих форм & $18,6 \pm 2,6$ & $18,3 \pm 3,4$ & $>0,05$ \\
\hline $\begin{array}{l}\text { Температура, тіла, } \\
\text { С }^{\circ}\end{array}$ & $38,2 \pm 0,2$ & $38,6 \pm 0,2$ & $>0,05$ \\
\hline СРП, мг/л & $88,2 \pm 10,3$ & $39,0 \pm 6,2$ & $<0,01$ \\
\hline
\end{tabular}

Аналіз показників кисневого бюджету у хворих 3 лактатом $>2,5$ ммоль/л та лактатом $<2,5$ ммоль/л не дав можливості виявити жодних достовірних відмінностей вивчаємих показників ( $>0,05)$ (табл. 3). Проте слід зазначити, що у хворих 3 нормальним лактатом спостерігалась тенденція до існування дещо кращих показників, що характеризують легеневий газообмін $\left(\mathrm{PaO}_{2} / \mathrm{FiO}_{2}, \mathrm{P}(\mathrm{A}-\mathrm{a}) \mathrm{O}_{2}, \mathrm{Qs} / \mathrm{Qt}\right)$. Рівень лактату не мав достовірних кореляцій із $\mathrm{VO}_{2}$ та $\mathrm{ITEO}_{2}$. Отже, продукція лактату при септичних станах у дітей зумовлена іншими, ніж системна гіпоксія чинниками, адже головні показники кисневого бюджету - доставка та споживання кисню у пацієнтів 3 лактатом $>2,5$ ммоль/л та лактатом $<2,5$ ммоль/л не лише не відрізнялись, але і відповідали нормальним позначкам, відповідно

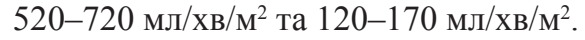

Таблиця 3

Показники кисневого бюджету залежно від рівня

\begin{tabular}{|c|c|c|c|}
\hline Показники & $\begin{array}{c}\text { Лактат } \\
>2,5 \text { ммоль/л }\end{array}$ & $\begin{array}{c}\text { Лактат } \\
<2,5 \text { ммоль/л }\end{array}$ & $\mathrm{p}$ \\
\hline $\mathrm{Hb}$, г/л & $106,8 \pm 3,9$ & $115,3 \pm 2,9$ & $>0,05$ \\
\hline $\mathrm{PaO}_{2}$, мм рт. ст. & $124,4 \pm 16,3$ & $124,9 \pm 10,9$ & $>0,05$ \\
\hline $\mathrm{SaO}_{2}, \%$ & $95,2 \pm 0,7$ & $96,5 \pm 0,7$ & $>0,05$ \\
\hline $\mathrm{CaO}_{2}$, мл & $137,7 \pm 4,6$ & $148,1 \pm 4,7$ & $>0,05$ \\
\hline $\mathrm{PvO}_{2}$, мм рт. ст. & $47,3 \pm 3,2$ & $44,8 \pm 2,5$ & $>0,05$ \\
\hline $\mathrm{ScvO}_{2}, \%$ & $68,4 \pm 3,1$ & $74,4 \pm 2,7$ & $>0,05$ \\
\hline $\mathrm{CvO}_{2}$, мЛ & $101,4 \pm 6,9$ & $111,9 \pm 5,2$ & $>0,05$ \\
\hline $\begin{array}{l}\mathrm{P}(\mathrm{A}-\mathrm{a}) \mathrm{O}_{2}, \mathrm{MM} \\
\text { рт.ст. }\end{array}$ & $184,2 \pm 46,7$ & $88,9 \pm 22,4$ & $>0,05$ \\
\hline $\mathrm{PaO}_{2} / \mathrm{FiO}_{2}$ & $304,9 \pm 43,8$ & $402,8 \pm 29,3$ & $>0,05$ \\
\hline $\mathrm{C}(\mathrm{A}-\mathrm{V}) \mathrm{O}_{2}, \mathrm{Mл} / \mathrm{л}$ & $41,6 \pm 6,2$ & $37,7 \pm 4,6$ & $>0,05$ \\
\hline Qs/Qt, \% & $26,1 \pm 3,9$ & $19,4 \pm 3,2$ & $>0,05$ \\
\hline $\mathrm{DO}_{2}$, мл/хв $/ \mathrm{M}^{2}$ & $528,9 \pm 26,4$ & $607,0 \pm 30,7$ & $>0,05$ \\
\hline $\mathrm{VO}_{2}, \mathrm{MЛ} / \mathrm{xв} / \mathrm{M}^{2}$ & $158,1 \pm 24,9$ & $154,5 \pm 19,4$ & $>0,05$ \\
\hline $\mathrm{ITEO}_{2}, \%$ & $28,0 \pm 3,0$ & $24,0 \pm 3,0$ & $>0,05$ \\
\hline
\end{tabular}
лактату $(\mathrm{x} \pm \mathrm{Sx})$

Вивчення основних показників центральної та легеневої гемодинаміки і діастолічної функції лівого шлуночка також не дало змогу виявити жодних достовірних відмінностей між хворими 3 лактатом $>2,5$ ммоль/л та лактатом $<2,5$ ммоль/л $(\mathrm{p}>0,05)$. Сдиним показником, за яким досліджувані групи достовірно відрізнялись, була ЧСС, яка у хворих із лактатом $>2,5$ ммоль/л достовірно перевищувала цей показник у хворих із лактатом $<2,5$ ммоль/л ( $<0,01)$ (табл. 4).

Таблиця 4

Показники гемодинаміки залежно від рівня лактату

\begin{tabular}{|c|c|c|c|}
\hline Показники & $\begin{array}{c}\text { Лактат } \\
>2,5 \text { ммоль/л }\end{array}$ & $\begin{array}{c}\text { Лактат } \\
<2,5 \text { ммоль/л }\end{array}$ & $\mathrm{p}$ \\
\hline ЧСС, уд/хв & $146,2 \pm 4,5$ & $127,0 \pm 4,2$ & $<0,01$ \\
\hline САТ, мм рт. ст. & $65,1 \pm 2,4$ & $70,8 \pm 2,0$ & $>0,05$ \\
\hline ІКДО, мл/м² & $45,5 \pm 2,5$ & $51,3 \pm 3,1$ & $>0,05$ \\
\hline УО, мл & $16,7 \pm 2,1$ & $19,3 \pm 2,2$ & $>0,05$ \\
\hline $\mathrm{XOC,} \mathrm{л/Хв}$ & $2,22 \pm 0,22$ & $2,32 \pm 0,24$ & $>0,05$ \\
\hline СІ, л/хв/ $/ \mathrm{M}^{2}$ & $3,87 \pm 0,16$ & $4,04 \pm 0,19$ & $>0,05$ \\
\hline$\Phi B, \%$ & $63,0 \pm 2,0$ & $65,0 \pm 2,0$ & $>0,05$ \\
\hline $\begin{array}{l}\text { ІЛСО, } \\
\text { Дин }{ }^{*}{ }^{*} \mathrm{~cm}_{-}-5 / \mathrm{m}^{2}\end{array}$ & $716,9 \pm 73,8$ & $589,3 \pm 62,8$ & $>0,05$ \\
\hline $\begin{array}{l}\text { ІЗПСО, } \\
\text { дин }{ }^{*}{ }^{*} \mathrm{~cm}_{-} 5 / \mathrm{m}^{2}\end{array}$ & $1398,4 \pm 90,3$ & $1463,0 \pm 87,1$ & $>0,05$ \\
\hline $\begin{array}{l}\text { Vmax Peak A } \\
(\mathrm{cm} / \mathrm{c})\end{array}$ & $80,9 \pm 4,8$ & $83,8 \pm 6,0$ & $>0,05$ \\
\hline $\begin{array}{l}\text { Vmax Peak E } \\
(\mathrm{cm} / \mathrm{c})\end{array}$ & $106,6 \pm 5,6$ & $120,5 \pm 6,2$ & $>0,05$ \\
\hline $\mathrm{E} / \mathrm{A}$ & $1,43 \pm 0,10$ & $1,67 \pm 0,18$ & $>0,05$ \\
\hline
\end{tabular}
$(\mathrm{x} \pm \mathrm{Sx})$ 
Отже, стан центральної гемодинаміки, включно iз показниками серцевого викиду та периферичного судинного опору, не впливає на продукцію лактату при сепсисі.

Але доцільно поставити запитання щодо можливості впливу регіональних гемодинамічних розладів на рівень лактатемії, адже відомо, що ішемія кишечника може спричиняти лактат-ацидоз, а гіпоперфузія печінки може гальмувати утилізацію лактату. Проте, вивчення показників кровоплину у печінковій артерії також не виявило жодних достовірних відмінностей між хворими 3 лактатом $>2,5$ ммоль/л та лактатом $<2,5$ ммоль/л (р>0,05) (табл. 5).

Таблиця 5 Показники кровообігу по печінковій артерії залежно від рівня лактату $(\mathrm{x} \pm \mathrm{Sx})$

\begin{tabular}{|l|c|c|c|}
\hline \multicolumn{1}{|c|}{ Показники } & $\begin{array}{c}\text { Лактат } \\
>2,5 \text { ммоль/л }\end{array}$ & $\begin{array}{c}\text { Лактат } \\
<2,5 \text { ммоль/л }\end{array}$ & $\mathrm{p}$ \\
\hline Vmax, cм/c & $66,32 \pm 5,54$ & $76,62 \pm 6,53$ & $>0,05$ \\
\hline Vmin, cм/c & $17,12 \pm 1,10$ & $19,80 \pm 1,11$ & $>0,05$ \\
\hline Vmean, cм/c & $33,52 \pm 2,39$ & $38,74 \pm 2,61$ & $>0,05$ \\
\hline PI, у. o. & $1,43 \pm 0,06$ & $1,39 \pm 0,07$ & $>0,05$ \\
\hline IR, у. o. & $0,72 \pm 0,02$ & $0,71 \pm 0,02$ & $>0,05$ \\
\hline Q, мл/хв. & $193,09 \pm 26,28$ & $258,63 \pm 55,74$ & $>0,05$ \\
\hline $\mathrm{Q} / \mathrm{m}, \mathrm{мл} / \mathrm{xв} / \mathrm{M}^{2}$ & $16,24 \pm 1,53$ & $21,52 \pm 2,81$ & $>0,05$ \\
\hline
\end{tabular}

Також не спостерігалось достовірних відмінностей показників кровоплину по іншому артеріальному стовбуру спланхнічної зони - селезінковій артерії ( $>0,05)$ (табл. 6).

Таблиця 6

Показники кровообігу по селезінковій артерії залежно від рівня лактату $(\mathrm{x} \pm \mathrm{Sx})$

\begin{tabular}{|c|c|c|c|}
\hline Показники & $\begin{array}{c}\text { Лактат } \\
>2,5 \text { ммоль/л }\end{array}$ & $\begin{array}{c}\text { Лактат } \\
<2,5 \text { ммоль/л }\end{array}$ & $\mathrm{p}$ \\
\hline Vmax, cм/c & $74,58 \pm 5,10$ & $79,54 \pm 5,19$ & $>0,05$ \\
\hline Vmin, $\mathrm{cm} / \mathrm{c}$ & $20,13 \pm 1,81$ & $24,52 \pm 1,87$ & $>0,05$ \\
\hline Vmean, cm/c & $38,28 \pm 2,70$ & $42,86 \pm 2,78$ & $>0,05$ \\
\hline PI, у. о. & $1,43 \pm 0,06$ & $1,39 \pm 0,07$ & $>0,05$ \\
\hline IR, y. o. & $0,73 \pm 0,02$ & $0,69 \pm 0,02$ & $>0,05$ \\
\hline $\mathrm{Q}$, мл/хв. & $314,34 \pm 59,82$ & $312,72 \pm 52,25$ & $>0,05$ \\
\hline $\mathrm{Q} / \mathrm{m}$, мл/хв/ $\mathrm{M}^{2}$ & $23,35 \pm 3,25$ & $24,57 \pm 2,55$ & $>0,05$ \\
\hline
\end{tabular}

Кровоплин по верхній мезентеріальній артерії, попри певну тенденцію до наявності більших його позначок у хворих із лактатом $<2,5$ ммоль/л, теж не мав достовірних відмінностей між досліджуваними групами (p>0,05) (табл. 7).

Таблиця 7

Показники кровообігу по верхній мезентеріальній артерії залежно від рівня лактату $(\mathrm{x} \pm \mathrm{Sx})$

\begin{tabular}{|l|c|c|c|}
\hline \multicolumn{1}{|c|}{ Показники } & $\begin{array}{c}\text { Лактат } \\
>2,5 \text { ммоль/л }\end{array}$ & $\begin{array}{c}\text { Лактат }<2,5 \\
\text { ммоль/л }\end{array}$ & $\mathrm{p}$ \\
\hline Vmax, см/c & $139,95 \pm 11,37$ & $168,58 \pm 14,76$ & $>0,05$ \\
\hline Vmin, cм/c & $21,91 \pm 1,92$ & $24,14 \pm 1,75$ & $>0,05$ \\
\hline Vmean, cм/c & $61,26 \pm 4,55$ & $72,29 \pm 5,56$ & $>0,05$ \\
\hline PI, у. о. & $1,88 \pm 0,06$ & $1,91 \pm 0,07$ & $>0,05$ \\
\hline IR, у. о. & $0,83 \pm 0,01$ & $0,83 \pm 0,01$ & $>0,05$ \\
\hline Q, мл/хв. & $789,65 \pm 101,60$ & $1034,41 \pm 178,43$ & $>0,05$ \\
\hline Q/m, мл/хв/M ${ }^{2}$ & $74,39 \pm 6,88$ & $76,27 \pm 6,18$ & $>0,05$ \\
\hline
\end{tabular}

Достовірних відмінностей кровоплину по ворітній вені між пацієнтами з лактатом $>2,5$ ммоль/л та лактатом $<2,5$ ммоль/л також не спостерігалось ( $>0,05)$ (табл. 8).

Таблиця 8

Показники кровообігу по ворітній вені залежно від рівня лактату $(\mathrm{x} \pm \mathrm{Sx})$

\begin{tabular}{|l|c|c|c|}
\hline \multicolumn{1}{|c|}{ Показники } & $\begin{array}{c}\text { Лактат } \\
>2,5 \text { ммоль/л }\end{array}$ & $\begin{array}{c}\text { Лактат } \\
<2,5 \text { ммоль/л }\end{array}$ & $\mathrm{p}$ \\
\hline Vmax, см/c & $23,19 \pm 1,55$ & $27,44 \pm 2,07$ & $>0,05$ \\
\hline Vmin, cм/c & $16,40 \pm 1,20$ & $19,27 \pm 1,30$ & $>0,05$ \\
\hline Vmean, cм/c & $18,66 \pm 1,30$ & $21,99 \pm 1,52$ & $>0,05$ \\
\hline PI, у. о. & $0,39 \pm 0,03$ & $0,36 \pm 0,03$ & $>0,05$ \\
\hline IR, у. o. & $0,30 \pm 0,02$ & $0,28 \pm 0,02$ & $>0,05$ \\
\hline Q, мл/хв. & $427,62 \pm 59,46$ & $534,53 \pm 78,91$ & $>0,05$ \\
\hline $\mathrm{Q} / \mathrm{m}, \mathrm{мл} / \mathrm{xв} / \mathrm{m}^{2}$ & $37,27 \pm 3,95$ & $48,16 \pm 6,11$ & $>0,05$ \\
\hline
\end{tabular}

Цілком зрозуміло, що відповідно до відсутності відмінностей кровоплину у магістральних венах та артеріях спланхнічної зони, не спостерігалось і достовірних відмінностей індексів спланхнічного кровообігу (p>0,05) (табл. 9).

Таблиця 9 Індекси спланхнічного кровообігу залежно від рівня лактату $(\mathrm{x} \pm \mathrm{Sx})$

\begin{tabular}{|l|c|c|c|}
\hline Показники & $\begin{array}{c}\text { Лактат }>2,5 \\
\text { ммоль/л }\end{array}$ & $\begin{array}{c}\text { Лактат }<2,5 \\
\text { ммоль/л }\end{array}$ & $\mathrm{p}$ \\
\hline IОК АН & $1141,49 \pm 150,65$ & $1315,76 \pm 283,74$ & $>0,05$ \\
\hline IОК АМ & $4637,68 \pm 573,05$ & $5354,04 \pm 934,43$ & $>0,05$ \\
\hline OК/СI АН & $30,57 \pm 3,90$ & $33,49 \pm 6,47$ & $>0,05$ \\
\hline OК/CI AM & $121,03 \pm 13,16$ & $138,46 \pm 24,32$ & $>0,05$ \\
\hline ЗПОК & $620,71 \pm 81,53$ & $776,47 \pm 118,83$ & $>0,05$ \\
\hline
\end{tabular}

Чутливі показники ниркової гіпоперфузії пульсаційний індекс та індекс резистентності правої та лівої магістральних ниркових вен у хворих із лактатом $>2,5$ ммоль/л та лактатом $<2,5$ ммоль/л також не мали достовірних відмінностей $(\mathrm{p}>0,05)$ (табл. 10).

Таблиця 10

Показники венозного ниркового кровообігу у хворих залежно від рівня лактату $(\mathrm{x} \pm \mathrm{Sx})$

\begin{tabular}{|l|c|c|c|}
\hline \multicolumn{1}{|c|}{ Показники } & $\begin{array}{c}\text { Лактат } \\
>2,5 \text { ммоль/л }\end{array}$ & $\begin{array}{c}\text { Лактат } \\
<2,5 \text { ммоль/л }\end{array}$ & $\mathrm{p}$ \\
\hline PI V ren D, у. о. & $0,79 \pm 0,08$ & $0,72 \pm 0,07$ & $>0,05$ \\
\hline PI V ren S, у. о. & $0,62 \pm 0,07$ & $0,65 \pm 0,08$ & $>0,05$ \\
\hline IR V ren D, у. o. & $0,48 \pm 0,03$ & $0,41 \pm 0,03$ & $>0,05$ \\
\hline IR V ren S, y. o. & $0,45 \pm 0,03$ & $0,41 \pm 0,04$ & $>0,05$ \\
\hline
\end{tabular}

Отже, у групах із високим та низьким лактатом не вдалось знайти суттєвих гемодинамічних відмінностей, як з боку показників центральної гемодинаміки, так і з боку доступних показників кровообігу у найважливіших судинних басейнах (мале коло, спланхнічна зона, нирки).

Аби запобігти помилковим висновкам 3 отриманих гемодинамічних показників, співставимо вміст вазоактивних медіаторів у хворих із лактатом $>2,5$ ммоль/л та лактатом <2,5 ммоль/л. Як можемо бачити, i тут достовірні відмінності відсутні (p>0,05) (табл. 11). 
Таблиця 11

Вміст вазоактивних медіаторів залежно від рівня лактату $(\mathrm{x} \pm \mathrm{Sx})$

\begin{tabular}{|l|c|c|c|}
\hline \multicolumn{1}{|c|}{ Показники } & $\begin{array}{c}\text { Лактат } \\
>2,5 \text { ммоль/л }\end{array}$ & $\begin{array}{c}\text { Лактат } \\
<2,5 \text { ммоль/л }\end{array}$ & $\mathrm{p}$ \\
\hline $\begin{array}{l}\text { Сумарні } \\
\text { метаболіти, } \\
\text { мкмоль/л }\end{array}$ & $42,49 \pm 4,64$ & $45,09 \pm 4,94$ & $>0,05$ \\
\hline $\begin{array}{l}\text { Нітрити, } \\
\text { мкмоль/л }\end{array}$ & $1,83 \pm 0,15$ & $1,75 \pm 0,12$ & $>0,05$ \\
\hline $\begin{array}{l}\text { Нітрати, } \\
\text { мкмоль/л }\end{array}$ & $40,60 \pm 4,60$ & $43,32 \pm 4,94$ & $>0,05$ \\
\hline $\begin{array}{l}\text { Ендотелін, } \\
\text { фмоль/л }\end{array}$ & $0,75 \pm 0,19$ & $1,11 \pm 0,44$ & $>0,05$ \\
\hline
\end{tabular}

Таким чином, отримані результати співставлення показників центральної та периферичної гемодинаміки, медіаторної ланки регуляції судинного тонусу, переконливо свідчать, що гіперлактатемія при септичних станах не пов'язана виключно із гемодинамічними розладами та розладами тканинної перфузії. Такий висновок цілком відповідає гіпотезі Gore D. C., Jahoor F., Hibbert J. M., DeMaria E.J., 1996, щодо провідної ролі гіперпродукції пірувату у тканинах із інсуліннезалежними механізмами надходження глюкози, але не нестачі тканинної перфузії у розвитку септичного лактат-ацидозу.

Отже, на підтвердження висловленої думки, звернемось до метаболічних показників. Цілком логічно, що у пацієнтів із лактатом $>2,5$ ммоль/л, порівняно із пацієнтами 3 лактатом $<2,5$ ммоль/л були достовірно меншими показники $\mathrm{pHv}, \mathrm{AB} \mathrm{v}, \mathrm{BB} \mathrm{v}$ та більший дефіцит основ $\pm \mathrm{BE}$, відповідно $(\mathrm{p}<0,01),(\mathrm{p}<0,05)$, $(\mathrm{p}<0,01)$ та $(\mathrm{p}<0,01)$.

Таблиця 12

Показники КОС та метаболізму залежно від рівня лактату $(\mathrm{x} \pm \mathrm{Sx})$

\begin{tabular}{|l|c|c|c|}
\hline \multicolumn{1}{|c|}{ Показники } & $\begin{array}{c}\text { Лактат } \\
>2,5 \text { ммоль/л }\end{array}$ & $\begin{array}{c}\text { Лактат } \\
<2,5 \text { ммоль/л }\end{array}$ & $\mathrm{p}$ \\
\hline $\mathrm{PaCO}_{2}$ мм рт. ст. & $32,9 \pm 3,4$ & $35,1 \pm 1,4$ & $>0,05$ \\
\hline $\mathrm{pH}$ v & $7,25 \pm 0,03$ & $7,35 \pm 0,02$ & $<0,01$ \\
\hline$\pm \mathrm{BE} \mathrm{v,} \mathrm{ммоль/л}$ & $-10,07 \pm 1,63$ & $-2,64 \pm 1,76$ & $<0,01$ \\
\hline $\mathrm{AB} \mathrm{v,} \mathrm{ммоль/л}$ & $16,52 \pm 1,06$ & $21,78 \pm 1,53$ & $<0,05$ \\
\hline $\mathrm{BB} \mathrm{v,} \mathrm{ммоль/л}$ & $36,44 \pm 1,57$ & $43,81 \pm 1,63$ & $<0,01$ \\
\hline $\begin{array}{l}\text { Глюкоза а, } \\
\text { ммоль/л }\end{array}$ & $7,31 \pm 0,99$ & $5,29 \pm 0,37$ & $>0,05$ \\
\hline $\begin{array}{l}\text { Глюкоза v, } \\
\text { ммоль/л }\end{array}$ & $6,68 \pm 0,65$ & $5,03 \pm 0,21$ & $<0,05$ \\
\hline $\begin{array}{l}\text { Лактат а, } \\
\text { ммоль/л }\end{array}$ & $4,46 \pm 0,91$ & $1,35 \pm 0,12$ & $<0,01$ \\
\hline $\begin{array}{l}\text { Лактат v, ммоль/л } \\
\text { Добова втрата } \\
\text { білку, г }\end{array}$ & $5,14 \pm 0,58$ & $1,53 \pm 0,37$ & $<0,001$ \\
\hline
\end{tabular}

Рівень лактату у центральній венозній та артеріальній крові у хворих із лактатом понад 2,5 ммоль/л, порівняно із хворими з лактатом менше 2,5 ммоль/л також був достовірно більшим, відповідно $(\mathrm{p}<0,001)$ та $(\mathrm{p}<0,01)$ (табл. 12).

Необхідно зазначити, що ми визначили наявність сильних зворотніх кореляційних зв'язків між лактатом та $\mathrm{pH}\left(\mathrm{r}_{\mathrm{s}}=0,73 ; \mathrm{p}<0,05\right)$; лактатом та $\mathrm{BE}$ $\left(\mathrm{r}_{\mathrm{s}}=0,69 ; \mathrm{p}<0,05\right) ;$ лактатом та $\mathrm{HCO} 3 \quad\left(\mathrm{r}_{\mathrm{s}}=-0,59\right.$; $\mathrm{p}<0,05)$; лактатом та $\mathrm{BB}\left(\mathrm{r}_{\mathrm{s}}=0,72 ; \mathrm{p}<0,05\right)$; та позитивного із лактатом та A gap $\left(\mathrm{r}_{\mathrm{s}}=0,63 ; \mathrm{p}<0,05\right)$. Більш цікавим фактом, що підтверджує висловлену думку щодо провідної ролі гіперглікемії та гіперметаболізму в утворенні лактат ацидозу при сепсисі здається достовірно вищій рівень глікемії та більша добова втрата білку, які спостерігались саме у хворих із лактатом понад 2,5 ммоль/л $(\mathrm{p}<0,05)$, (табл. 12). Вміст лактату у артеріальній крові мав позитивну кореляцію із глюкозою артеріальної крові, $\left(\mathrm{r}_{\mathrm{s}}=0,44 ; \mathrm{p}=0,01\right)$ та глюкозою венозної крові $\left(\mathrm{r}_{\mathrm{s}}=0,46 ; \mathrm{p}=0,007\right)$. Вміст лактату у венозній крові корелював із глюкозою артеріальної крові $\left(\mathrm{r}_{\mathrm{s}}=0,35 ; \mathrm{p}=0,04\right)$ та глюкозою венозної крові $\left(\mathrm{r}_{\mathrm{s}}=0,29 ; \mathrm{p}=0,01\right)$. Тут також варто звернутись до показників С3ВО у хворих із лактатом $>2,5$ ммоль/л та лактатом $<2,5$ ммоль/л і нагадати, що у пацієнтів із нормальним лактатом рівень СРП, хоча і перевищував норму, але був достовірно нижчим, ніж у пацієнтів із лактатом $>2,5$ ммоль/л (p<0,01) (табл. 2). Таким чином підтверджується менша виразності септичного гіперметаболізму у групі хворих із низьким лактатом, адже, як добре відомо, синтез СРП та білковий катаболізм тісно пов'язані процеси, які відбивають перебудову метаболізму у відповідь на активацію ССЗВ. Отже, наявність метаболічного ацидозу з збільшеним аніонним інтервалом у дітей з сепсисом з високою імовірністю свідчить про наявність гіперлактатемії. Проте, ці показники не можуть бути використані для констатації гіпоперфузії, а навпаки, мають бути застосовані для діагностики септичної перебудови метаболічних процесів. Але, чи означають отримані результати, що визначення показників КОС та лактату не мають прогностичної цінності? Звернімося до порівняння тяжкості органних розладів та летальності у пацієнтів iз лактатом $>2,5$ ммоль/л та лактатом $<2,5$ ммоль/л. Отримані дані свідчать, що гіперлактатемія характеризується достовірно більшим показником за шкалою SOFA $(p<0,001)$ i достовірно більшою летальністю $(\mathrm{p}<0,05)$ (табл. 13).

Таблиця 13

Показники тяжкості стану та виходів залежно від рівня лактату $(\mathrm{x} \pm \mathrm{Sx})$

\begin{tabular}{|l|c|c|c|}
\hline \multicolumn{1}{|c|}{ Показники } & $\begin{array}{c}\text { Лактат } \\
>2,5 \text { ммоль/л }\end{array}$ & $\begin{array}{c}\text { Лактат } \\
<2,5 \text { ммоль/л }\end{array}$ & $\mathrm{p}$ \\
\hline Бал за Glasgow & $9,4 \pm 0,6$ & $10,6 \pm 0,6$ & $>0,05$ \\
\hline Бал за SOFA & $7,1 \pm 0,6$ & $4,1 \pm 0,6$ & $<0,01$ \\
\hline Померло & $14(26,0 \pm 7,0 \%)$ & $5(10,0 \pm 5,0 \%)$ & $<0,05$ \\
\hline
\end{tabular}

Показник лактату також мав позитивні кореляційні зв'язки із оцінкою за шкалою SOFA та тяжкістю стану $\left(\mathrm{r}_{\mathrm{s}}=0,46 ; \mathrm{p}=0,017\right),\left(\mathrm{r}_{\mathrm{s}}=0,58 ; \mathrm{p}<0,001\right)$ відповідно. Отже, гіперлактаемія $\epsilon$ важливим маркером тяжкості поліорганних розладів та предиктором летальності при септичних станах у дітей. Але, слід підкреслити, що, імовірно, при септичних станах формуються дві патологічні ланки, які безпосередньо впливають на формування СПОН, але не є абсолютно пов'язаними між собою. По-перше, це розлади тканинної перфузії, пов’язані із відносною нестачею фізіологічних 
вазодилятаторів (NO) на тлі надмірної продукції ендотеліну, які формують ішемічне ушкодження життєво важливих органів і тканин. По-друге, це метаболічні розлади, які характеризуються гіперглікемією, гіперметаболізмом, надмірним споживанням окремими видами клітин глюкози і розвитком гіперлактатеміі. Ці метаболічні розлади призводять до токсичного ушкодження життєво важливих органів і також сприяють формуванню поліорганних розладів, навіть за умов задовільної системної та периферичної гемодинаміки.

\section{6. Висновки}

Таким чином, підводячи підсумок отриманим у дослідженні результатам, маємо зробити наступні висновки:

1. Гіперлактатемія при септичних станах у дітей зумовлена не стільки тканинною гіпоксією внаслідок гіпоперфузії, скільки гіперметаболізмом та гіперглікемією.

2. Гіперлактатемія є незалежним маркером несприятливого прогнозу і високого ризику розвитку $\mathrm{CПОН.}$

3. Попри те, що рівень лактатемії корелює iз тяжкістю стану хворого, він також не може бути повноцінним маркером адекватності кисневого транспорту, адже також не має кореляційних зв'язків із показниками серцевого викиду, транспорту та споживання кисню при сепсисі у дітей.

\section{Література}

1. Leverve, X. Lactate: A key metabolite in the intercellular metabolic interplay [Text] / X. Leverve, I. Mustafa // Crit. Care - 2002. - Vol. 6. - P. 284-285.

2. Марино, П. Л. Интенсивная терапия [Текст] / П. Л. Марино; пер. с англ. - М.: «ГЭОТАР-Медиа, 2010. - 768 с.

3. Костюченко, С. С. Кислотно-щелочной баланс в интенсивной терапии. [Текст] / С. С. Костюченко. - Минск, 2008. - 175 c.

4. Дементьева, И. И. Клинические аспекты состояния и регуляции кислотно-основного гомеостаза [Текст] / И. И.Дементьева. - М.: «ЮНИМЕД-пресс», 2002. - 80 с.

5. Bridges, E. Cardiovascular Aspects of Septic Shock [Text] / E. Bridges, M. S. Dukes // Critical Care Nurse. 2005. - Vol. 25. - P. 14-40.
6. Gore, D. C. Lactic acidosis during sepsis is related to increased pyruvate production, not deficitis in tissue oxygen availability [Text] / D. C. Gore, F. Jahoor, J. M. Hibbert et al. // Annals of Surgery. - 1996. - Vol. 224, Issue 1. - P. 225-229. doi: 10.1097/00000658-199607000-00015

7. Marik, P. E. Stress-hyperglycemia, insulin and immunomodulation in sepsis [Text] / P. E. Marik, M. Raghavan // Intensive Care Medicine. - 2004. - Vol. 30, Issue 5. - P. 748-756. doi: 10.1007/s00134-004-2167-y

8. Maric, P. E. Monitoring theraputic interventions in critically ill septic patients [Text] / P. E. Maric // Nutrition in Clinical Practice. - 2004. - Vol. 19, Issue 5. - P. 423-432. doi: $10.1177 / 0115426504019005423$

9. Морган-мл, Дж. Е. Клиническая анестезиология. Книга 2-я [Текст] / Дж. Е. Морган-мл., М. С. Михайл; пер. с англ. - М.-СПб.: Издательство БИНОМ - Невский Диалект, 2010. $-366 \mathrm{c}$.

10. Басманов, С. М. Інтенсивна терапія в педіатрії [Текст] / С. М. Басманов, Г. І. Белебезьєв, А. В. Бєляєв та ін. - К.: Медицина, 2008. - 520 с.

\section{References}

1. Leverve, X., Mustafa, I. (2002). Lactate: A key metabolite in the intercellular metabolic interplay, 6, 284-285.

2. Marino, P. L. (2010). Intensivnaya therapia [The ICU Book]. GEOTAR-Media, 768.

3. Kostuchenko, S. S. (2009). Kislotno-shcelochny balans v intensivny therapiy [ABB in ICU]. Minsk, 175.

4. Dementeva, I. I. (2002). Klinicheskie aspekty sostoyaniya i regulatsii kislotn-osnovnogo gomeostasa [Clinical aspects of acid-base regulation]. Moscow, Russia: Unimed-press, 80.

5. Bridges, E., Dukes, M. (2005). Cardiovascular Aspects of Septic Shock. Critical Care Nurse, 25, 14-40.

6. Gore, D., Jahoor, F., Hibbert, J. (1996). Lactic acidosis during sepsis is related to increased pyruvate production, not deficitis in tissue oxygen availability. Annals of Surgery, 224 (1), 225-229. doi: 10.1097/00000658-199607000-00015

7. Marik, P., Raghavan, M. (2004). Stress-hyperglycemia, insulin and immunomodulation in sepsis, Intensive Care Medicine, 30 (5), 748-756. doi: 10.1007/s00134-004-2167-y

8. Maric, P. (2004). Monitoring theraputic interventions in critically ill septic patients, Nutrition in Clinical Practice, 19 (5), 423-432. doi: 10.1177/0115426504019005423

9. Morgan, G. E., Mikhail, M. S. (2010). Klinichesraya anestesiologia [Clinical anesthesiology]. Moscow, S-t Pb, Russia: Binom-Nevsky Dialekt, 366.

10. Belebesiyev, G. I. (Ed.) (2008). Intensivnaya terapiy v pediatriy [Pediatric Critical Care]. Kiev: Meditsina, 520.

Корсунов Володимир Анатолійович, доктор медичних наук, професор кафедри дитячої анестезіології та інтенсивної терапії, доцент, Харківська медична академія післядипломної освіти, вул. Корчагинців, 58, м. Харків, Україна, 61000

E-mail Korsunoff@ukr.net 